\title{
Synthesis of new 2'-deoxy-2'-fluoro-4'-azido nucleoside analogues as potent anti-HIV agents
}

\author{
Qiang Wang ${ }^{\mathrm{a}}$, Weidong Hua ${ }^{\mathrm{a}}$, Shuyang Wang ${ }^{\mathrm{a}}$, Zhenliang Pan ${ }^{\mathrm{a}}$, Le Tao ${ }^{\mathrm{b}}$, Xiaohe Guo $^{\mathrm{b}}$,

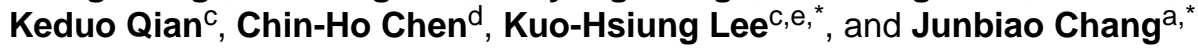 \\ aDepartment of Chemistry, Zhengzhou University, Zhengzhou 450001, PR China \\ bHena Key Laboratory of Fine Chemical, Zhengzhou 450002, PR China \\ 'Natural Products Research Laboratories, UNC Eshelman School of Pharmacy, University of \\ North Carolina, Chapel Hill, NC 27599-7568, USA \\ dDepartment of Surgery, Duke University Medical Center, Durham, NC 27710, USA \\ 'Chinese Medicine Research and Development Center, China Medical University and Hospital, \\ Taichung, Taiwan
}

\begin{abstract}
We prepared 1-(4'-azido-2'-deoxy-2'-fluoro- $\beta$-D-arabinofuranosyl)cytosine (10) and its hydrochloride salt (11) as potential antiviral agents based on the favorable antiviral profiles of 4'substituted nucleosides. Compounds $\mathbf{1 0}$ and $\mathbf{1 1}$ were synthesized from 1,3,5-O-tribenzoyl-2deoxy-2-fluoro-D-arabinofuranoside in multiple steps, and their structures were unequivocally established by IR, ${ }^{1} \mathrm{H}$ NMR, ${ }^{13} \mathrm{C}$ NMR, and ${ }^{19} \mathrm{~F}$ NMR spectroscopy, HRMS, and X-ray crystallography. Compounds $\mathbf{1 0}$ and $\mathbf{1 1}$ exhibited potent anti-HIV-1 activity $\left(\mathrm{EC}_{50}: 0.3\right.$ and 0.13 $\mathrm{nM}$, respectively) without significant cytotoxicity in concentrations up to $100 \mu \mathrm{M}$. Compound $\mathbf{1 1}$ exhibited extremely potent anti-HIV activity against NL4-3 (wild-type), NL4-3 (K101E), and RTMDR viral strains, with $\mathrm{EC}_{50}$ values of $0.086,0.15$, and $0.11 \mathrm{nM}$, respectively. Due to the high potency of 11, it was also screened against an NIH Reagent Program NRTI-resistant virus panel containing eleven mutated viral strains and for cytotoxicity against six different human cell lines. The results of this screening indicated that $\mathbf{1 1}$ is a novel NRTI that could be developed as an antiAIDS clinical trial candidate to overcome drug-resistance issues.
\end{abstract}

\section{Keywords}

4'-Azido-2'-deoxy-2'-fluoro nucleosides; Anti-HIV activity; Nucleoside reverse transcriptase inhibitor (NRTI); Drug resistance

\footnotetext{
(C) 2011 Elsevier Masson SAS. All rights reserved.

*Corresponding authors. For K.H.L. Tel.: (919) 962-0066; fax: (919) 966-3893 (K.H. Lee). Tel.: +86-371-67783017; fax: +86-371-67783017 (J. Chang), khlee@unc.edu (K.H. Lee), changjunbiao@zzu.edu.cn (J. Chang).

Publisher's Disclaimer: This is a PDF file of an unedited manuscript that has been accepted for publication. As a service to our customers we are providing this early version of the manuscript. The manuscript will undergo copyediting, typesetting, and review of the resulting proof before it is published in its final citable form. Please note that during the production process errors may be discovered which could affect the content, and all legal disclaimers that apply to the journal pertain.
} 


\section{Introduction}

Since the discovery of the human immunodeficiency virus (HIV) in 1983, AIDS has become the leading infectious cause of death worldwide. According to the World Health Organization (07 AIDS Epidemic Update), there were 33.2 million people living with AIDS worldwide in 2007, 2.1 million deaths from AIDS, and 2.5 million newly infected patients with AIDS. Over the last two decades, tremendous effort has been directed to the discovery and development of novel agents for the treatment of HIV infections and great successes have been achieved. So far, there are more than 20 approved anti-HIV drugs, belonging to seven classes [1].

Nucleoside reverse transcriptase inhibitors (NRTIs) are one of the most important classes of compounds active against HIV replication and have been used extensively to treat HIV infection [2]. However, the long term use of antiviral nucleoside analogs is inevitably associated with delayed toxicity and/or development of drug-resistant virus [3-6], which limits their effectiveness as an AIDS treatment. Therefore, there remains a need for the development of novel anti-HIV agents with better therapeutic indices, new mechanisms of action, and activity against HIV strains resistant to currently available drugs.

All clinical NRTIs belong to the family of 2', $3^{\prime}$-dideoxynucleoside (ddN) [7]. As the chain terminator of proviral DNA biosynthesis, the ddN structure has been assumed to be essential for an active nucleoside derivative. However, resistant HIV variants and other side effects have emerged. Resistance to these ddNs results from HIV mutants that have acquired the ability to discriminate between ddN and physiologic 2'-deoxynucleoside (dN), do not accept ddN into the active center of their reverse transcriptase (RT), and selectively cut off the incorporated ddN from their proviral DNA terminus. Therefore, nucleoside drugs that could prevent the emergence of drug-resistant HIV variants must have a $3^{\prime}-\mathrm{OH}$ as the chain terminator of proviral DNA biosynthesis.

A 4'- $C$-substituted-2'-deoxynucleoside (4'sdN) satisfies these conditions, because 4'sdN has all of the functional groups of $\mathrm{dN}$, making it difficult for HIV to discriminate between a $4^{\prime} \mathrm{sdN}$ and $\mathrm{dN}$. At the same time, the 3'-OH group of 4'sdN would not be useful for elongation of proviral DNA biosynthesis. Thus, 4 'sdN could be the chain-terminator of proviral DNA biosynthesis and active against HIV as well as HIV strains resistant to current ddN drugs. In addition, modification of the carbohydrate moiety of nucleosides with electron-withdrawing groups can greatly affect the nucleoside's electronic properties and conformational shape [8-14], which often leads to dramatically improved activities. Therefore, we incorporated a fluorine atom, which has the strongest electron-withdrawing property of the halogens atoms, into our newly designed 4'sdN. Moreover, azido, cyano, and ethynyl groups, which have characteristic electronic and structural features due to their $s p$ hybridization, are present in many biologically active compounds [15-17]. It has been proposed that the furanose ring of 4'-C-azidothymidine exhibits an unnatural 3 '- $C$-endo conformation, and the compound was active against multidrug-resistant strains of HIV $\left(\mathrm{EC}_{50}: 0.34 \mu \mathrm{M}\right)$ [18]. Therefore, we were interested in designing novel 4'sdN compounds with such substitutions at the $4^{\prime}$-position. Herein, we report the synthesis and evaluation of 1-(4'-azido-2'-deoxy-2'-fluoro- $\beta$-D-arabinofuranosyl)cytosine (10) (Fig. 1) as a novel potent NRTI that couldovercome drug -resistanceproblems [19-21].

\section{Chemistry}

The synthesis of $\mathbf{1 0}$ is illustrated in Scheme 1. According to the reported method [8, 13, 1925], treatment of commercially available 1,3,5- $O$-tribenzoyl-2-deoxy-2-fluoro-Darabinofuranoside (1) with $\mathrm{HBr}-\mathrm{HOAc}(45 \%)$ in dichloromethane (DCM) gave exclusively the $\alpha$-bromide 2, which was coupled with silylated uracil in chloroform to provide the $\beta$ - 
nucleoside analog $\mathbf{3}$ in a good yield after recrystallization. Deprotection of $\mathbf{3}$ with methanolic ammonia afforded nucleoside $\mathbf{4}$ in excellent yield. The 4 '-azido substitution was introduced using the following procedure modified from the previously reported method [26]. Treatment of 4 with $\mathrm{I}_{2} / \mathrm{Ph}_{3} \mathrm{P}$ in tetrahydrofuran (THF) followed by elimination in the presence of sodium methoxide (NaOMe) gave 4'-methylene-nucleoside 6 . Treatment of 6 with $\mathrm{ICl} / \mathrm{NaN}_{3}$ in THF afforded 4'-azido-nucleoside 7. Benzoylation of $\mathbf{7}$ followed by treatment with $m$-chloroperbenzoic acid ( $m$-CPBA) in the presence of $m$-chlorobenzoic acid ( $m$-CBA) yielded a protected 4'-azido-uridine analog 9 . Treatment of 9 with triazole/ $/ \mathrm{POCl}_{3}$ followed by methanolic ammonia gave our target $\mathbf{1 0}$. Compound $\mathbf{1 0}$ was dissolved in methanol and treated with a solution of hydrogen chloride in ethyl acetate. The product separated as a solid and was collected by filtration to afford the hydochloride salt (11) of $\mathbf{1 0}$. The solid-state structure of $\mathbf{1 1}$ was determined by single-crystal X-ray crystallography (Fig. 2). Crystallographic data (excluding structure factors) for the structures in this paper have been deposited with the Cambridge Crystallographic Data Centre as supplementary publication (nos. CCDC 740473). Copies of the data can be obtained, free of charge, on application to CCDC, 12 Union Road, Cambridge CB2 1EZ, UK, (fax: +44-(0)1223-336033 or e-mail: deposit@ccdc.cam.ac.uk).

\section{Results and discussion}

The anti-HIV activity of $\mathbf{1 0}$ and $\mathbf{1 1}$ was first evaluated in vitro according to standard procedures using efavirenz (EFV) and zidovudine (AZT) as controls (Table 1) [27-31]. Compounds 10 and 11 exhibited extremely potent antiviral activity with $\mathrm{EC}_{50}$ values of 0.3 and $0.13 \mathrm{nM}$, respectively, compared with EFV $\left(\mathrm{EC}_{50}: 1.2 \mathrm{nM}\right)$ and $\mathrm{AZT}\left(\mathrm{EC}_{50}: 47 \mathrm{nM}\right)$. The increased activity of $\mathbf{1 1}$ compared with $\mathbf{1 0}$ likely reflects its increased solubility of $\mathbf{1 1}$ in water [32]. Both compounds did not show significant cytotoxicity in concentrations up to $100 \mu \mathrm{M}$ against the MT-2 cell line using the MTT assay. In the further evaluation of 11, we discovered that it retained its sub-nanomolar activity against drug-resistant HIV strains NL4-3 (K101E) and RTMDR (Table 2). K101E tends to decrease viral susceptibility to all nucleoside RT inhibitors, while RTMDR is a multiple RT inhibitor-resistant strain, which is insensitive to AZT, ddI, nevirapine, and other NNRTIs. In our screening, 11 exhibited extremely potent anti-HIV activity against NL4-3 (wild-type), NL4-3 (K101E), and RTMDR, with $\mathrm{EC}_{50}$ values of $0.086,0.15$, and $0.11 \mathrm{nM}$, respectively. These findings suggested that $\mathbf{1 1}$ has a great potential to be developed as a novel NRTI.

Therefore, in the following study, we further evaluated the anti-HIV potential of $\mathbf{1 1}$ using a panel of eleven NRTI resistant viral strains from the NIH Reagent Program. As shown in Table 3, 11 retained its nanomolar activity against resistant strains 7324-1, 7324-4, 7303-3, $35764-2$, and 56252-1 with $\mathrm{EC}_{50}$ values of $0.595,0.735,0.56,0.42,0.525 \mathrm{nM}$, respectively, which were similar to that of $\mathbf{1 1}$ against the wild type NL4-3 $\left(\mathrm{EC}_{50}: 0.318 \mathrm{nM}\right)$. However, 11 partially or completely lost its nanomolar inhibitory activity against 10076-4, 7295-1, 4755-5, 6463-13, 1617-1, and 29129-2. After carefully analyzing the mutations of these resistant viral strains, we discovered that one single mutation M184V may lead to the substantially reduced antiviral activity of $\mathbf{1 1}$. This M184V mutation in RT was discovered previously to be 3TC treatment-associated, and it was also found that the M184V mutation increases the HIV sensitivity to AZT in AZT-resistant viruses, suggesting that compound $\mathbf{1 1}$ may be used in combination with AZT to reduce the influence of resistance issues.

The cytotoxicity profiles of $\mathbf{1 1}$ were further evaluated using six human cell lines different from the previously used MT-2 cell line (Table 4). A Promega CellTiter-Glo Luminescent Cell Viability Assay was used to determine the number of viable cells based on quantitation of the presence of ATP, which signals the presence of metabolically active cells. Compound 11 showed little cytotoxicity against TZM-BL, HEPG-2, and 293T cells with $\mathrm{IC}_{50}$ values 
over $140 \mu \mathrm{M}$, resulting in therapeutic index (TI) values of $>280,000$. Comparatively, 11 showed some cytotoxicity against MT4, ACH-2, and PBMC cells with $\mathrm{IC}_{50}$ values of 0.12 , 0.11 , and $0.15 \mu \mathrm{M}$, and corresponding TI values of 1418, 1255, and 1709. Overall, 11 showed less toxicity to adherent cells compared to suspension cells. Nevertheless, the TI values were still greater than at least one thousand.

Regarding mechanism of action, compound $\mathbf{1 0}$ is likely to have a strong binding in the active site of HIV RT due to the introduction of fluorine at the 2'-position. Although compound 10 possesses a 3'-hydroxy group, it might act like a DNA chain terminator similar to 4'-azido thymidine (Fig. 3). Based on the drug profile shown in Table 3 against resistant virus strains, D67 and M184 are likely the two critical amino acid residues in the NRTI binding site of HIV-1 RT that interact intimately with the compound. NRTI resistant viruses with $\mathrm{D} 67 \mathrm{~N}$ or M184V mutation are markedly resistant to compound $\mathbf{1 0}$. Thus, the compound is likely to bind between the palm and the finger subdomains of HIV-1 RT and make critical interactions with residues including D67 and M184.

\section{Conclusion}

In summary, novel 4'sdN compounds $\mathbf{1 0}$ and $\mathbf{1 1}$ were designed, synthesized, and evaluated for anti-HIV activity. The hydrochloride salt $\mathbf{1 1}$ retained its sub-nanomolar activity against NRTI-resistant (K101E) and multi-drug-resistant HIV strains (RTMDR). In further studies, 11 also showed nanomolar activity against resistant viral strains, except for the M184V single mutation. Compound $\mathbf{1 1}$ showed little cytotoxicity against adherent cells and marginal cytotoxicity against suspension cells with TI values over one thousand. Overall, compound $\mathbf{1 1}$ merits further development as an anti-AIDS clinical trial candidate.

\section{Experimental}

All chemical reagents were commercially available and column chromatography was performed on silica gel 200-300 mesh (Yantai Silica Gel Co. LTD). Analytical TLC was performed on silica gel $\mathrm{GF}_{254}$. Melting points were recorded with an XT-4 melting point apparatus and are uncorrected. IR spectra were obtained on a NICOLET 6700 spectrometer. ${ }^{1} \mathrm{H},{ }^{19} \mathrm{~F}$, and ${ }^{13} \mathrm{C}$ NMR spectra were obtained with a Bruker $\mathrm{AV}-300$ spectrometer. Chemical shifts are reported as $\delta(\mathrm{ppm})$ downfield with respect to an internal standard of tetramethylsilane (TMS). High-resolution mass spectra (HRMS-ESI) were obtained on a Micro ${ }^{\mathrm{TM}}$ Q-TOF Mass Spectrometer. Elemental analyses were performed with a Carlo-Erba $1106 \mathrm{C}, \mathrm{H}$, and $\mathrm{N}$ analyzer. LC-MS spectra were measured on an Agilent MSD-1100 ESI-MS/MS system. X-ray crystallography was obtained on Rigaku Saturn 724 CCD diffractometer.

\subsection{Synthesis of 1-(2-deoxy-2-fluoro-3,5-di-O-benzoyl- $\beta$-D-arabino-furanosyl)uracil (3)}

To a solution of 1,3,5-O-tribenzoyl-2-deoxy-2-fluoro-D-arabinofuranoside (1) (20.0 g, 43.1 $\mathrm{mmol})$ in anhydrous DCM $(400 \mathrm{~mL})$ was added $\mathrm{HBr}-\mathrm{HOAc}(45 \% \mathrm{v} / \mathrm{v}, 50 \mathrm{~mL}, 271 \mathrm{mmol})$ dropwise under nitrogen at $0 \mathrm{C}$ and the resulting solution was stirred at room temperature for $20 \mathrm{~h}$. The solution was washed with saturated $\mathrm{NaHCO}_{3}(3 \times 100 \mathrm{~mL})$, dried over $\mathrm{Na}_{2} \mathrm{SO}_{4}$, filtered, and concentrated to give compound $\mathbf{2}$ as syrup, which was used in the next step without further purification.

A mixture of uracil $(12.6 \mathrm{~g}, 113.0 \mathrm{mmol})$ and $\left(\mathrm{NH}_{4}\right)_{2} \mathrm{SO}_{4}(1.57 \mathrm{~g})$ in hexamethyldisilazane (HMDS) (1.5 L) was refluxed under nitrogen for $20 \mathrm{~h}$, and the homogeneous solution obtained was evaporated to dryness under vacuum to give the silylated uracil. To the silylated uracil residue was added a solution of compound 2 in $\mathrm{CHCl}_{3}(800 \mathrm{~mL})$ and the mixture was refluxed under nitrogen for $24 \mathrm{~h}$. The reaction was quenched by addition of ice- 
water and filtered. The aqueous layer was extracted with DCM $(3 \times 200 \mathrm{~mL})$ and the combined organic solution was washed with brine, dried over $\mathrm{Na}_{2} \mathrm{SO}_{4}$, filtered, and concentrated to give a white solid, which was recrystallized with 5\% EtOH-DCM to give compound $3(16.7 \mathrm{~g}, 84.2 \%)$. ${ }^{1} \mathrm{H}$ NMR $\left(300 \mathrm{MHz}, \mathrm{CDCl}_{3}\right) \delta 8.35$ (1H, brs, $\left.\mathrm{NH}\right), 7.43-8.11$ $(11 \mathrm{H}, \mathrm{m}, \mathrm{Ar}-\mathrm{H}, \mathrm{H}-6), 6.33\left(1 \mathrm{H}, \mathrm{dd}, J=21.59,2.93 \mathrm{~Hz}, \mathrm{H}-1^{\prime}\right), 5.69(1 \mathrm{H}, \mathrm{d}, J=8.05 \mathrm{~Hz}$, H-5), $5.63\left(1 \mathrm{H}, \mathrm{dd}, J=17.20,2.93 \mathrm{~Hz}, \mathrm{H}-3^{\prime}\right), 5.34\left(1 \mathrm{H}, \mathrm{dd}, J=50.13,2.93 \mathrm{~Hz}, \mathrm{H}-2^{\prime}\right), 4.78$ $\left(2 \mathrm{H}, \mathrm{d}, J=4.39 \mathrm{~Hz}, \mathrm{H}-5^{\prime}\right), 4.52\left(1 \mathrm{H}, \mathrm{m}, \mathrm{H}-4^{\prime}\right)$; ESI- MS: $m / z 455[\mathrm{M}+\mathrm{H}]^{+}$; Anal. calcd $\left(\mathrm{C}_{23} \mathrm{H}_{19} \mathrm{FN}_{2} \mathrm{O}_{7}\right): \mathrm{C}, 60.79 ; \mathrm{H}, 4.21 ; \mathrm{N}, 6.16$; found: $\mathrm{C}, 60.75 ; \mathrm{H}, 4.24 ; \mathrm{N}, 6.11$.

\subsection{Synthesis of 1-(2-deoxy-2-fluoro- $\beta$-D-arabinofuranosyl)uracil (4)}

A solution of compound $\mathbf{3}(7.79 \mathrm{~g}, 17.1 \mathrm{mmol})$ in saturated $\mathrm{NH}_{3}-\mathrm{MeOH}(200 \mathrm{~mL})$ was stirred at room temperature for $24 \mathrm{~h}$ and evaporated to dryness under reduced pressure. DCM $(25 \mathrm{~mL})$ was added to the residue and the mixture was stirred at room temperature for $1 \mathrm{~h}$. The white solid was collected by filtration to give compound $4(3.93 \mathrm{~g}, 93.0 \%) .{ }^{1} \mathrm{H}$ NMR $\left(300 \mathrm{MHz}, \mathrm{DMSO}-d_{6}\right) \delta 11.35(1 \mathrm{H}, \mathrm{brs}, \mathrm{NH}), 7.71(1 \mathrm{H}, \mathrm{dd}, J=8.05,1.46 \mathrm{~Hz}, \mathrm{H}-6)$, $6.10\left(1 \mathrm{H}, \mathrm{dd}, J=16.10,4.39 \mathrm{~Hz}, \mathrm{H}-1^{\prime}\right), 5.87\left(1 \mathrm{H}, \mathrm{d}, J=5.12 \mathrm{~Hz}, 3^{\prime}-\mathrm{OH}\right), 5.64(1 \mathrm{H}, \mathrm{d}, J=$ $8.05 \mathrm{~Hz}, \mathrm{H}-5), 5.08\left(1 \mathrm{H}, \mathrm{t}, J=5.85 \mathrm{~Hz}, 5^{\prime}-\mathrm{OH}\right), 5.03(1 \mathrm{H}, \mathrm{ddd}, J=52.69,4.03,2.93 \mathrm{~Hz}$, H-2'), $4.21\left(1 \mathrm{H}, \mathrm{dm}, J=19.76 \mathrm{~Hz}, \mathrm{H}-3^{\prime}\right), 3.79\left(1 \mathrm{H}, \mathrm{m}, \mathrm{H}-4^{\prime}\right), 3.60$ (2H, m, H-5'); ESI-MS: $\mathrm{m} / \mathrm{z} 269[\mathrm{M}+\mathrm{Na}]^{+}$; Anal. calcd $\left(\mathrm{C}_{9} \mathrm{H}_{11} \mathrm{FN}_{2} \mathrm{O}_{5}\right)$ : C, 43.91; H, 4.50; N, 11.38;found : C, 43.90; $\mathrm{H}, 4.29 ; \mathrm{N}, 11.33$.

\subsection{Synthesis of 1-(2,5-dideoxy-2-fluoro-5-iodo- $\beta$-D-arabino-furanosyl)uracil (5)}

To a solution of compound 4 (3.73 g, $15.2 \mathrm{mmol})$, imidazole (2.06 g, $30.3 \mathrm{mmol})$, and triphenylphosphine $(5.96 \mathrm{~g}, 22.7 \mathrm{mmol})$ in THF $(100 \mathrm{~mL})$ was added a solution of iodine $(5.77 \mathrm{~g}, 22.7 \mathrm{mmol})$ in THF $(50 \mathrm{~mL})$ dropwise at $0{ }^{\circ} \mathrm{C}$. The reaction mixture was stirred at room temperature overnight and quenched with a saturated solution of $\mathrm{Na}_{2} \mathrm{SO}_{3}$, extracted with EtOAc $(2 \times 100 \mathrm{~mL})$. The combined organic solution was washed with water, brine, dried over $\mathrm{Na}_{2} \mathrm{SO}_{4}$, filtered, and concentrated to yield a thick oil, which was purified by silica gel column chromatography $(1-5 \% \mathrm{MeOH}$ in DCM) to afford compound $5(4.51 \mathrm{~g}$, $83.5 \%) .{ }^{1} \mathrm{H}$ NMR $\left(300 \mathrm{MHz}, \mathrm{DMSO}-d_{6}\right) \delta 11.50(1 \mathrm{H}, \mathrm{br} \mathrm{s}, \mathrm{NH}), 7.58(1 \mathrm{H}, \mathrm{dd}, J=8.14$, $1.95 \mathrm{~Hz}, \mathrm{H}-6), 6.17$ (1H, dd, $\left.J=18.40,3.99 \mathrm{~Hz}, \mathrm{H}-1^{\prime}\right), 6.15$ (1H, br, 3'-OH), 5.67 (1H, d, $J$ $=8.14 \mathrm{~Hz}, \mathrm{H}-5), 5.08\left(1 \mathrm{H}, \mathrm{ddd}, J=52.41,3.84,2.55 \mathrm{~Hz}, \mathrm{H}-2^{\prime}\right), 4.14(1 \mathrm{H}, \mathrm{ddd}, J=19.68$, $\left.4.21,2.65 \mathrm{~Hz}, \mathrm{H}-3^{\prime}\right), 3.87\left(1 \mathrm{H}, \mathrm{dd}, J=11.02,5.19 \mathrm{~Hz}, \mathrm{H}-4^{\prime}\right), 3.43-3.57(\mathrm{~m}, 2 \mathrm{H}) ;{ }^{13} \mathrm{C}$ NMR $\left(75 \mathrm{MHz}\right.$, DMSO- $\left.d_{6}\right) \delta 6.2,76.7,82.0,83.0,95.3,101.4,141.2,150.0,162.8$; ESI-MS: $\mathrm{m} / z$ $379[\mathrm{M}+23]^{+}$; Anal. calcd $\left(\mathrm{C}_{9} \mathrm{H}_{10} \mathrm{FIN}_{2} \mathrm{O}_{4}\right)$ : C, 30.36; H, 2.83; N, 7.87; found: C, 30.30; H, $2.88 ; \mathrm{N}, 7.84$.

\subsection{Synthesis of 1-(2,5-dideoxy-2-fluoro- $\beta$-D-arabino-4-eno-furanosyl)uracil (6)}

A solution of compound $5(4.2 \mathrm{~g}, 11.8 \mathrm{mmol})$ in dry $\mathrm{MeOH}(40 \mathrm{~mL})$ containing $\mathrm{MeONa}$ (25\% wt in $\mathrm{MeOH}, 10.2 \mathrm{~mL}, 47.3 \mathrm{mmol}$ ) was heated to $65^{\circ} \mathrm{C}$ for $3 \mathrm{~h}$ and an additional aliquot of $\mathrm{MeONa}(25 \% \mathrm{wt}$ in $\mathrm{MeOH}, 3.4 \mathrm{~mL}$ ) was added. After $30 \mathrm{~min}$, the reaction mixture was allowed to stay at room temperature overnight and brine was added. The mixture was adjusted to $\mathrm{pH} 3$ by addition of $1 \mathrm{~N} \mathrm{HCl}$ and the mixture was extracted with EtOAc $(2 \times 300$ $\mathrm{mL}$ ). The combined organic solution was dried over $\mathrm{Na}_{2} \mathrm{SO}_{4}$, filtered, and concentrated. The residue was purified by silica gel column chromatography (2-5\% MeOH in DCM) to afford compound $6(1.94 \mathrm{~g}, 72.1 \%) .{ }^{1} \mathrm{H}$ NMR $\left(300 \mathrm{MHz}, \mathrm{CDCl}_{3}\right) \delta 9.05(1 \mathrm{H}, \mathrm{br} \mathrm{s}, \mathrm{NH}), 7.32(1 \mathrm{H}$, dd, $J=8.16,2.31 \mathrm{~Hz}, \mathrm{H}-6), 6.62\left(1 \mathrm{H}, \mathrm{dd}, J=20.97,2.79 \mathrm{~Hz}, \mathrm{H}-1^{\prime}\right), 5.76(1 \mathrm{H}, \mathrm{d}, J=8.22 \mathrm{~Hz}$, H-5), $5.09\left(1 \mathrm{H}, \mathrm{dd}, J=51.44,2.95 \mathrm{~Hz}, \mathrm{H}-2^{\prime}\right), 4.76\left(1 \mathrm{H}, \mathrm{d}, J=2.74 \mathrm{~Hz},=\mathrm{CH}_{2}\right), 4.73(1 \mathrm{H}, \mathrm{d}$, $\left.J=11.46 \mathrm{~Hz}, \mathrm{H}-3^{\prime}\right), 4.52\left(1 \mathrm{H}, \mathrm{d}, J=2.74 \mathrm{~Hz},=\mathrm{CH}_{2}\right)$; ESI-MS: $\mathrm{m} / z 227[\mathrm{M}-\mathrm{H}]^{+}$; Anal. calcd $\left(\mathrm{C}_{9} \mathrm{H}_{9} \mathrm{FN}_{2} \mathrm{O}_{4}\right)$ : C, 47.37; H, 3.98; N, 12.28;found : C, 47.43; H, 3.86; N, 12.13 . 


\subsection{Synthesis of 1-(4-azido-2,5-dideoxy-2-fluoro-5-iodo- $\beta$-D-arabino-furanosyl)uracil (7)}

To a suspension of $\mathrm{NaN}_{3}(1.38 \mathrm{~g}, 21.3 \mathrm{mmol})$ in THF $(50 \mathrm{~mL})$ at $0{ }^{\circ} \mathrm{C}$ was added $\mathrm{ICl}(2.31$ $\mathrm{g}, 14.2 \mathrm{mmol})$. After 10 minutes, a solution of compound 6 (1.62 g, $7.10 \mathrm{mmol})$ in THF (16 $\mathrm{mL}$ ) was added dropwise to the mixture and the reaction mixture was stirred at room temperature overnight. Aqueous $\mathrm{Na}_{2} \mathrm{SO}_{3}$ solution was added and the mixture extracted with EtOAc $(3 \times 250 \mathrm{~mL})$. The combined organic solution was dried over $\mathrm{Na}_{2} \mathrm{SO}_{4}$, filtered, and concentrated. The residue was purified by silica gel column chromatography $(1-5 \% \mathrm{MeOH}$ in DCM) to afford compound 7 (1.82 g, 64.6\%). IR KBr): $2119 \mathrm{~cm}^{-1}\left(\mathrm{~N}_{3}\right) ;{ }^{1} \mathrm{H}$ NMR (300 $\left.\mathrm{MHz}, \mathrm{MeOH}-d_{4}\right) \delta 7.68(1 \mathrm{H}, \mathrm{dd}, J=8.16,1.87 \mathrm{~Hz}, \mathrm{H}-6), 6.46(1 \mathrm{H}, \mathrm{dd}, J=16.07,4.39 \mathrm{~Hz}$, H-1'), 5.74(1H, d, $J=8.12 \mathrm{~Hz}, \mathrm{H}-5), 5.22\left(1 \mathrm{H}, \mathrm{ddd}, J=52.93,4.36,3.30 \mathrm{~Hz}, \mathrm{H}-2^{\prime}\right), 4.65$ $\left(1 \mathrm{H}, \mathrm{dd}, J=18.67,3.31 \mathrm{~Hz}, \mathrm{H}-3^{\prime}\right), 3.69\left(2 \mathrm{H}, \mathrm{m}, \mathrm{H}-5^{\prime}\right)$; ESI-MS: $\mathrm{m} / z .220[\mathrm{M}+23]^{+}$; Anal. calcd $\left(\mathrm{C}_{9} \mathrm{H}_{9} \mathrm{FIN}_{5} \mathrm{O}_{4}\right)$ : C, 27.22; H, 2.28; N, 17.64;found : C, 27.09; H, 2.23; N, 17.73.

\subsection{Synthesis of 1-(4-azido-2,5-dideoxy-2-fluoro-3-O-benzoyl-5-iodo- $\beta$-D- arabinofuranosyl)uracil (8)}

To a solution of compound $7(1.17 \mathrm{~g}, 2.95 \mathrm{mmol})$ in DCM $(130 \mathrm{~mL})$ were added $\mathrm{Et}_{3} \mathrm{~N}(0.82$ $\mathrm{mL}, 5.90 \mathrm{mmol}$ ) and a catalytic amount of 4-dimethylaminopyridine. The reaction mixture was cooled to $0^{\circ} \mathrm{C}$ and benzyl chloride $(0.41 \mathrm{~mL}, 3.54 \mathrm{mmol})$ was added. After $20 \mathrm{~min}$, water and $2 \mathrm{M} \mathrm{K}_{2} \mathrm{CO}_{3}$ were added, and the mixture was extracted with EtOAc $(400 \mathrm{~mL})$. The organic layer was washed with brine $(2 \times 50 \mathrm{~mL})$, dried over $\mathrm{Na}_{2} \mathrm{SO}_{4}$, filtered, and concentrated. The residue was purified by silica gel column chromatography $(0.1-1 \%$ $\mathrm{MeOH}$ in DCM) to afford compound $8(1.2 \mathrm{~g}, 81.2 \%)$. IR (KBr): $2118 \mathrm{~cm}^{-1}\left(\mathrm{~N}_{3}\right) ;{ }^{1} \mathrm{H} \mathrm{NMR}$ $\left(300 \mathrm{MHz}, \mathrm{DMSO}-d_{6}\right) \delta 11.63(1 \mathrm{H}, \mathrm{br} \mathrm{s}, \mathrm{NH}), 7.57-8.09(6 \mathrm{H}, \mathrm{m}, \mathrm{Ar}-\mathrm{H}$ and $\mathrm{H}-6), 6.52(1 \mathrm{H}$, dd, $\left.J=18.69,5.52 \mathrm{~Hz}, \mathrm{H}-1^{\prime}\right), 6.07\left(1 \mathrm{H}, \mathrm{dd}, J=21.57,4.05 \mathrm{~Hz}, \mathrm{H}-3^{\prime}\right), 5.82(1 \mathrm{H}, \mathrm{ddd}, J=$ $\left.52.21,5.32,4.38 \mathrm{~Hz}, \mathrm{H}-2^{\prime}\right), 5.78$ (1H, d, $\left.J=8.14 \mathrm{~Hz}, \mathrm{H}-5\right), 3.99$ (2H, q, $\left.J=11.66 \mathrm{~Hz}, \mathrm{H}-5^{\prime}\right)$; ESI-MS: $m / z 524[\mathrm{M}+23]^{+}$; Anal. calcd $\left(\mathrm{C}_{16} \mathrm{H}_{13} \mathrm{FIN}_{5} \mathrm{O}_{5}\right): \mathrm{C}, 38.34 ; \mathrm{H}, 2.61 ; \mathrm{N}$, 13.97; found : C, 38.26; H, 2.48; N, 13.85 .

\subsection{Synthesis of 1-(4-azido-2-deoxy-2-fluoro-3-0-benzoyl-5-0-(3-chlorobenzoyl)- $\beta$-D- arabinofuranosyl)uracil (9)}

To a solution of $8(1.10 \mathrm{~g}, 2.19 \mathrm{mmol})$ in DCM $(100 \mathrm{~mL})$ and water $(60 \mathrm{~mL})$ were added successively $\mathrm{K}_{2} \mathrm{HPO}_{4}(0.76 \mathrm{~g}, 4.38 \mathrm{mmol}), n-\mathrm{Bu}_{4} \mathrm{NHSO}_{4}(0.82 \mathrm{~g}, 2.41 \mathrm{mmol})$, and $m$-CBA $(0.38 \mathrm{~g}, 2.41 \mathrm{mmol})$. The reaction mixture was cooled to $0{ }^{\circ} \mathrm{C}$ and $m$-CPBA $(77 \%, 1.47 \mathrm{~g}$, $6.57 \mathrm{mmol}$ ) was added. The reaction mixture was stirred at room temperature overnight. $\mathrm{Na}_{2} \mathrm{SO}_{3}$ was added and the mixture was extracted with EtOAc $(500 \mathrm{~mL})$. The combined organic solution was washed with $\mathrm{Na}_{2} \mathrm{SO}_{3}(5 \%)$, brine, dried over $\mathrm{Na}_{2} \mathrm{SO}_{4}$, filtered, and concentrated. The residue was purified by silica gel column chromatography $(0.1-0.5 \%$ $\mathrm{MeOH}$ in DCM) to provide compound $9(667 \mathrm{mg}, 57.5 \%)$. IR (KBr): $2117 \mathrm{~cm}^{-1}\left(\mathrm{~N}_{3}\right) ;{ }^{1} \mathrm{H}$ NMR (300 MHz, $\left.\mathrm{CDCl}_{3}\right) \delta 7.41-8.10(10 \mathrm{H}, \mathrm{m}, \mathrm{Ar}-\mathrm{H}$ and $\mathrm{H}-6), 6.63(1 \mathrm{H}, \mathrm{dd}, J=18.36,3.61$ $\left.\mathrm{Hz}, \mathrm{H}-1^{\prime}\right), 5.73-5.84\left(2 \mathrm{H}, \mathrm{m}, \mathrm{H}-3^{\prime}\right.$ and $\left.\mathrm{H}-5\right), 5.45\left(1 \mathrm{H}, \mathrm{ddd}, J=51.37,3.55,2.03 \mathrm{~Hz}, \mathrm{H}-2^{\prime}\right)$, $4.86\left(2 \mathrm{H}, \mathrm{q}, J=11.87 \mathrm{~Hz}, \mathrm{H}-5^{\prime}\right)$; ESI-MS: $m / z 553[\mathrm{M}+23]^{+}$; Anal. c alcd $\left(\mathrm{C}_{23} \mathrm{H}_{17} \mathrm{FClN}_{5} \mathrm{O}_{7}\right)$ : C, 52.14; H, 3.23; N, 13.22; found : C, 52.03; H, 3.22; N, 13.00 .

\subsection{Synthesis of 1-(4-azido-2-deoxy-2-fluoro)- $\beta$-D-arabinofuranosyl)cytosine (10)}

To a solution of compound $9(0.40 \mathrm{~g}, 0.75 \mathrm{mmol})$ in DCM $(15 \mathrm{~mL})$ was added 1,2,4-triazole $(0.57 \mathrm{~g}, 8.25 \mathrm{mmol})$ followed by pyridine $(0.67 \mathrm{~mL}, 8.25 \mathrm{mmol})$. The solution was cooled to $0{ }^{\circ} \mathrm{C}$ and $\mathrm{POCl}_{3}(0.39 \mathrm{~mL}, 3.75 \mathrm{mmol})$ was added. The solution was stirred at $0{ }^{\circ} \mathrm{C}$ for $2 \mathrm{~h}$ then room temperature overnight. The reaction was quenched with water and the mixture was extracted with DCM $(2 \times 250 \mathrm{~mL})$. The combined organic solution was dried over $\mathrm{Na}_{2} \mathrm{SO}_{4}$, filtered, and concentrated. The residue was dissolved in THF $(40 \mathrm{~mL})$ and $\mathrm{NH}_{4} \mathrm{OH}$ $(33 \%, 40 \mathrm{~mL})$ was added. The reaction mixture was stirred at room temperature for $1 \mathrm{~h}$. 
Solvent was removed and the residue was dissolved in $\mathrm{MeOH}(40 \mathrm{~mL})$ and $7 \mathrm{~N} \mathrm{NH}_{3}$ in $\mathrm{MeOH}(40 \mathrm{~mL})$ was added. The solution was stirred at room temperature overnight. The solution was concentrated to dryness under reduced pressure and the residue was purified by silica gel column chromatography (1-5\% MeOH in DCM) to give compound 10 (92 mg, $41.1 \%)$ as a white solid. mp: $86-87^{\circ} \mathrm{C}$; IR (KBr): $2118 \mathrm{~cm}^{-1}\left(\mathrm{~N}_{3}\right) ;{ }^{1} \mathrm{H}$ NMR $(300 \mathrm{MHz}$, $\left.\mathrm{MeOH}-d_{4}\right) \delta 7.80(1 \mathrm{H}, \mathrm{d}, J=7.57 \mathrm{~Hz}, \mathrm{H}-6), 6.50\left(1 \mathrm{H}, \mathrm{dd}, J=12.10,4.67 \mathrm{~Hz}, \mathrm{H}-1^{\prime}\right), 5.97$ $(1 \mathrm{H}, \mathrm{d}, J=7.57 \mathrm{~Hz}, \mathrm{H}-5), 5.21\left(1 \mathrm{H}, \mathrm{dt}, J=53.52,4.48 \mathrm{~Hz}, \mathrm{H}-2^{\prime}\right), 4.49(1 \mathrm{H}, \mathrm{dd}, J=21.63$, $\left.4.34 \mathrm{~Hz}, \mathrm{H}-3^{\prime}\right), 3.84\left(2 \mathrm{H}, \mathrm{s}, \mathrm{H}-5^{\prime}\right) ;{ }^{13} \mathrm{C}$ NMR $\left(75.47 \mathrm{MHz}, \mathrm{MeOH}-d_{4}\right) \delta 63.4,76.5(J=25.2$ $\mathrm{Hz}), 84.8(J=17.2 \mathrm{~Hz}), 96.1,96.2(J=193.4 \mathrm{~Hz}), 98.6(J=7.5 \mathrm{~Hz}), 143.0,157.9$, $167.8 ;{ }^{19} \mathrm{~F}$ NMR (282.4 MHz, MeOH- $\left.d_{4}\right)$ : -202.5; ESI-TOF/MS for $\mathrm{C}_{9} \mathrm{H}_{11} \mathrm{FN}_{6} \mathrm{O}_{4}$ : calcd $287.0904[\mathrm{M}+\mathrm{H}]^{+}$; found: $287.0905[\mathrm{M}+\mathrm{H}]^{+}$; Anal. calcd $\left(\mathrm{C}_{9} \mathrm{H}_{11} \mathrm{FN}_{6} \mathrm{O}_{4}\right): \mathrm{C}, 37.77 ; \mathrm{H}, 3.87$; N, 29.36; found: C, 37.53; H, 3.90; N, 29.19.

\subsection{Synthesis of 1-(4-azido-2-deoxy-2-fluoro)- $\beta$-D-arabinofuranosyl)cytosine hydrochloride salt (11)}

Compound $10(50 \mathrm{mg}, 0.17 \mathrm{mmol})$ was dissolved in $\mathrm{MeOH}(1 \mathrm{~mL})$ and treated with a solution of hydrogen chloride $(20 \mathrm{mmol})$ in EtOAc $(10 \mathrm{~mL})$. The product separated as a solid and was collected by filtration to afford the hydrochloride salt of compound $\mathbf{1 0}(34 \mathrm{mg}$, 61.1\%). IR (KBr): $2117 \mathrm{~cm}^{-1}\left(\mathrm{~N}_{3}\right) ;{ }^{1} \mathrm{H}-\mathrm{NMR}\left(\mathrm{D}_{2} \mathrm{O}\right) \delta 7.94(1 \mathrm{H}, \mathrm{dd}, J=8.05,1.10 \mathrm{~Hz}, \mathrm{H}-6)$, $6.54\left(1 \mathrm{H}, \mathrm{dd}, J=10.98,5.12 \mathrm{~Hz}, \mathrm{H}-1^{\prime}\right), 6.26(1 \mathrm{H}, \mathrm{d}, J=8.05 \mathrm{~Hz}, \mathrm{H}-5), 5.39(1 \mathrm{H}, \mathrm{dt}, J=$ $\left.52.69,5.12 \mathrm{~Hz}, \mathrm{H}-2^{\prime}\right), 4.58\left(1 \mathrm{H}, \mathrm{dd}, J=21.59,4.76 \mathrm{~Hz}, \mathrm{H}-3^{\prime}\right), 3.97(2 \mathrm{H}, \mathrm{q}, J=12.66 \mathrm{~Hz}$, H-5'); ESI-MS: $m / z 287[\mathrm{M}+\mathrm{H}]^{+}$.

\subsection{Single-crystal $X$-ray diffraction analysis of hydrochloride salt $\mathbf{1 1}$}

$\mathrm{C}_{9} \mathrm{H}_{11} \mathrm{FN}_{6} \mathrm{O}_{4} \cdot \mathrm{HCl}$, fw $=322.70$, Monoclinic P2(1), $a=6.5738(13) \AA, b=14.309(3) \AA, c=$ 7.3271(15) $\AA, \alpha=\gamma=90^{\circ}, \beta=99.68(3)^{\circ}, V=679.4(2) \AA^{3}, Z=2, \rho_{\text {calcd }}=1.577 \mathrm{Mg} / \mathrm{m}^{3}$, $\lambda\left(\right.$ Mo- $\left.K_{\alpha}\right)=0.71073 \AA, \mu=0.320 \mathrm{~mm}^{-1}, \boldsymbol{F}(000)=332, T=293(2)$. A colorless $0.22 \times 0.18 \times$ $0.14 \mathrm{~mm}^{3}$ crystal was used for data collection. The theta range for data collection was 3.14 to $26.01^{\circ}$ with 2633 reflections collected.

\subsection{Anti-HIV (wt) activity assay}

Vesicular stomatitis virus glycoprotein (VSV-G) plasmid was co-transfected with envdeficient HIV vector, pNL4-3.luc. $\mathrm{R}^{-} \mathrm{E}^{-}$[24, 25], into 293 cells by using modified $\mathrm{Ca}_{3}\left(\mathrm{PO}_{4}\right)_{2}$ method. ${ }^{26}$ Briefly, 293 cells (100 mm plate) were transfected with $8 \mu \mathrm{g}$ HIV vector alone or with $3 \mu \mathrm{g}$ VSVG DNA. After $16 \mathrm{~h}$, plates were washed with phosphatebuffered saline, and fresh medium was added into the plates. After post-infection for $48 \mathrm{~h}$, the supernatant was harvested and filtered through a $0.45 \mu \mathrm{m}$ filter. The supernatant contains VSVG/HIV pseudotyped virions and can be used directly or stored at $-80^{\circ} \mathrm{C}$.

One hour prior to infection, MT-2 cells were plated on 24-well plates at the density of $1.2 \times 10^{5}$ cells per well. Compound was incubated with target cells for 15 minutes prior to adding VSVG/HIV-1 $(0.5 \mathrm{~mL} /$ well $)$ for infection. The same amount of solvent alone was used as control. After post-infection for $48 \mathrm{~h}$, cells were spin down and supernatant was discarded. Cells were lysed in $50 \mu \mathrm{l}$ Cell Lysis Reagent (Promega). Luciferase activity of the cell lysate was measured by a FB15 luminometer (Berthold Detection System) according to the manufacturer's instructions. Compounds $\mathbf{1 0}$ and $\mathbf{1 1}$ showed dose-dependent inhibition activity on $\mathrm{HIV}-1$ replication with $\mathrm{EC}_{50}$ values of $0.3 \mathrm{nM}$ and $0.13 \mathrm{nM}$, respectively, and thus, were more potent than AZT $\left(\mathrm{EC}_{50}: 47 \mathrm{nM}\right)$. 


\subsection{Cell viability assay}

Compounds $\mathbf{1 0}$ and $\mathbf{1 1}$ were evaluated for cell viability by MTT methods [27]. MTT assay was performed in MT-2 cell line. Both compounds had no significant effect on cell growth or any cytotoxic effect on MT-2 cells at a final concentration of $100 \mu \mathrm{M}$.

\subsection{Anti-HIV replication assay against NL4-3 (K101E) and RTMDR strains in TZM-bl cell lines}

A previously described HIV-1 infectivity assay was used in the experiments [28]. A 96-well cell culture plate was used to set up the virus replication screening sassy. NL4-3 (K101E) or RTMDR at a multiplicity of infection (MOI) of 0.001 was used to infect TZM-bl cells. Culture supernatants were collected on day 4 post-infection for a p24 assay using an ELISA kit from PerkinElmer.

\section{Acknowledgments}

J. Chang thanks the National Natural Science Foundation of China (\#20672030; \#30825043) for financial support. Thanks are also due to a grant AI-33066 from the National Institute of Allergy and Infectious Diseases (NIAID) awarded to K.H. Lee.

\section{Abbreviations}

IR

infrared

NMR nuclear magnetic resonance

HRMS high resolution mass spectrometry

RT reverse transcriptase

RTMDR reverse transcriptase multi-drug resistant

NRTI nucleoside reverse transcriptase inhibitor

NNRTI non-nucleoside reverse transcriptase inhibitor

HIV human immunodeficiency virus

AIDS acquired immunodeficiency syndrome

dN 2'-deoxynucleoside

ddN 2',3'-dideoxynucleoside

4'sdN 4'- $C$-substituted-2'-deoxynucleoside

DCM dichloromethane

THF tetrahydrofuran

$m$-CPBA $m$-chloroperbenzoic acid

$m$-CBA $m$-chlorobenzoic acid

EFV efavirenz

AZT zidovudine

HMDS hexamethyldisilazane

VSV-G vesicular stomatitis virus glycoprotein

\section{References}

1. De Clercq E. Nat Rev Drug Discov. 2007; 6:1001-1018. [PubMed: 18049474] 
2. Sharma PL, Nurpeisov V, Hernandez-Santiago B, Beltran T, Schinazi RF. Curr Top Med Chem. 2004; 4:895-919. [PubMed: 15134548]

3. Brinkman K, ter Hofstede HJ, Burger DM, Smeitink JA, Koopmans PP. AIDS. 1998; 12:17351744. [PubMed: 9792373]

4. Chen CH, Cheng YC. J Biol Chem. 1989; 264:11934-11937. [PubMed: 2745424]

5. Shulman N, Winters M. Curr Drug Targets Infect Disord. 2003; 3:273-281. [PubMed: 14754429]

6. Lewis W, Day BJ, Copeland WC. Nat Rev Drug Discov. 2003; 2:812-822. [PubMed: 14526384]

7. Ohrui H, Kohgo S, Kitano K, Sakata S, Kodama E, Yoshimura K, Matsuoka M, Shigeta S, Mitsuya H. J Med Chem. 2000; 43:4516-4525. [PubMed: 11087576]

8. Watanabe KA, Reichman U, Hirota K, Lopez C, Fox JJ. J Med Chem. 1979; 22:21-24. [PubMed: 218006]

9. Hertel LW, Kroin JS, Misner JW, Tustin JM. J Org Chem. 1988; 53:2406-2409.

10. Marquez VE, Tseng CKH, Mitsuya H, Aoki S, Kelley JA, Ford H Jr, Driscoll JS. J Med Chem. 1990; 33:978-985. [PubMed: 2106581]

11. Pai SB, Liu SH, Zhu YL, Chu CK, Cheng YC. Antimicrob Agents Chemother. 1996; 40:380-386. [PubMed: 8834884]

12. Chun BK, Schinazi RF, Cheng YC, Chu CK. Carbohydr Res. 2000; 328:49-59. [PubMed: 11005575]

13. Klumpp K, Kalayanov G, Ma H, Pogam SL, Leveque V, Jiang WR, Inocencio N, Witte AD, Rajyaguru S, Tai E, Chanda S, Irwin MR, Sund C, Winqist A, Maltseva T, Eriksson S, Usova E, Smith M, Alker A, Najera I, Cammack N, Martin JA, Johansson NG, Smith DB. J Biol Chem. 2008; 283:2167-2175. [PubMed: 18003608]

14. Schaerer OD, Verdine GL. J Am Chem Soc. 1995; 117:10781-10782.

15. Minakawa N, Takeda T, Sasaki T, Matasuda A, Ueda T. J Med Chem. 1991; 34:778-786. [PubMed: 1995901]

16. Siddiqui MA, Hughes SH, Boyer PL, Mitsuya H, Van QN, George C, Sarafinanos SG, Marquez VE. J Med Chem. 2004; 47:5041-5048. [PubMed: 15456247]

17. Graul A, Rabasseda X, Castaner J. Drugs Future. 1998; 23:133-141.

18. Maag H, Rydzewski RH, McRberts MJ, Crawford-Ruth D, Verheyden JPH, Prisbe EJ. J Med Chem. 1992; 35:1440-1451. [PubMed: 1573638]

19. Chang, J.; Bao, X.; Wang, Q.; Guo, X.; Wang, W.; Qi, X. Preparation of 2'-fluoro-4'-substituted nucleoside analogs as antiviral agents. Chinese Patent Application No: CN 2007-10137548. 20070807. Chinese Patent No: CN 101177442A, 20080514

20. Chang, J. 2'-Fluoro-4'-substituted nucleosides, the preparation and use. International Application No: PCT/CN2008/001239. 20080627. International Patent No: WO2009009951, 20090122

21. Chang, J. 2'-Fluorine-4'-substituted nucleoside analogues, preparation methods and uses thereof. US Patent. US 2010/0234584A1, 20100916.

22. Ma T, Pai SB, Zhu YL, Lin JS, Shanmuganathan K, Du J, Wang C, Kim H, Newton MG, Cheng YC, Chu CK. J Med Chem. 1996; 39:2835-2843. [PubMed: 8709113]

23. Jin YH, Bae M, Byun YJ, Kim JH, Chun MW. Arch Pharm Res. 1995; 18:364-365.

24. Smith DB, Kalayanov G, Sund C, Wingvist A, Maltseva T, Leveque VJP, Rajyaguru S, Pogam SL, Najera I, Benkestock K, Zhou XX, Kaiser AC, Maag H, Cammack N, Martin JA, Swallow S, Johansson NG, Klumpp K, Smith M. J Med Chem. 2009; 52:2971-2978. [PubMed: 19341305]

25. Pharmasset Inc. 2',4'-Substituted nucleosides as antiviral agents. International Patent. WO2009067409, 20090528. US Patent No: US 20090318380, 20091224

26. Smith DB, Martin JA, Klumpp K, Baker SJ, Blomgren PA, Devos R, Granycome C, Hang J, Hobbs CJ, Jiang WR, Laxton C, Pogam SL, Leveque V, Ma H, Maile G, Merrett JH, Pichota A, Sarma K, Smith M, Swallow S, Symons J, Vesey D, Najera I, Cammack N. Bioog Med Chem Lett. 2007; 17:2570-2576.

27. He J, Choe S, Walker R, Di Marzio P, Morgan DO, Landau NR. J Virol. 1995; 69:6705-6711. [PubMed: 7474080]

28. Connor RI, Chen BK, Choe S, Landau NR. Virology. 1995; 206:935-944. [PubMed: 7531918] 
29. Rong L, Bates P. J Virol. 1995; 69:4847-4853. [PubMed: 7609052]

30. Carmichael J, DeGraff WG, Gazdar AF, Minna JD, Mitchell JB. Cancer Res. 1987; 47:943-946. [PubMed: 3802101]

31. Qian K, Yu D, Chen CH, Huang L, Morris-Natschke SL, Nitz TJ, Salzwedel K, Reddick M, Allaway GP, Lee KH. J Med Chem. 2009; 52:3248-3258. [PubMed: 19388685]

32. The solubility of compound $\mathbf{1 0}$ is $3.1 \mathrm{~g}$ in $100 \mathrm{~g}$ water. The solubility of compound $\mathbf{1 1}$ is $14.3 \mathrm{~g}$ in $100 \mathrm{~g}$ water. 


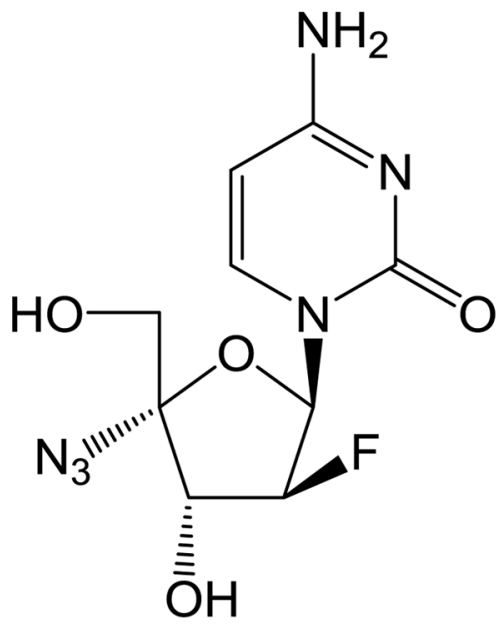

10

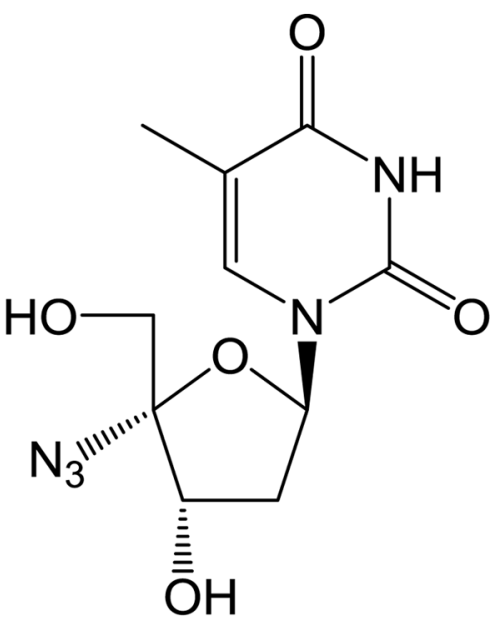

4'-azido-thymidine

Fig. 1.

Structures of 1-(4'-Azido-2'-deoxy-2'-fluoro- $\beta$-D-arabinofuranosyl)cytosine (10) and Its Design Lead 4'-Azido-thymidine. 

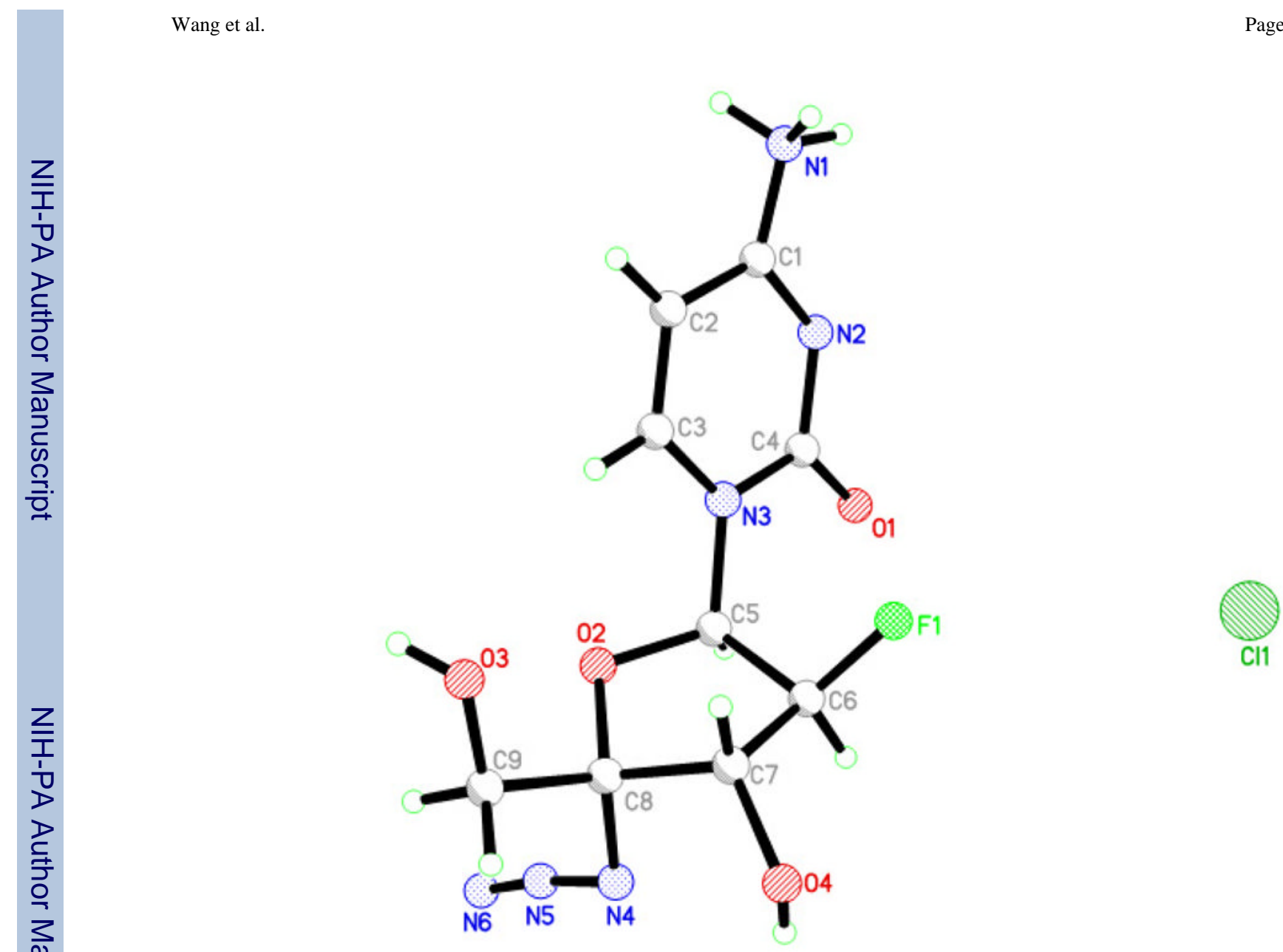

Fig. 2.

X-ray Crystallographic Structure of Hydrochloride Salt 11. 

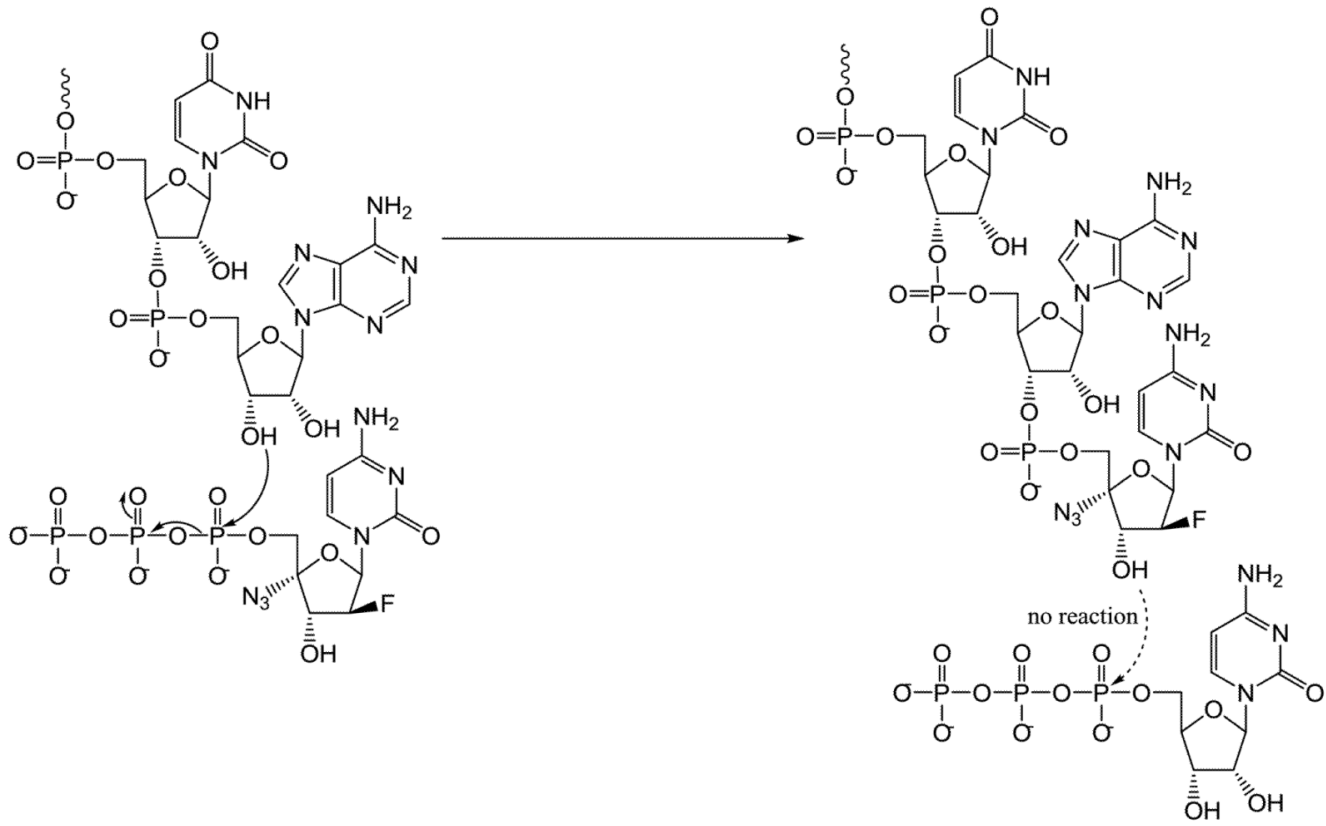

Fig 3.

Mechanism of Phosphorylated Compound 10. 

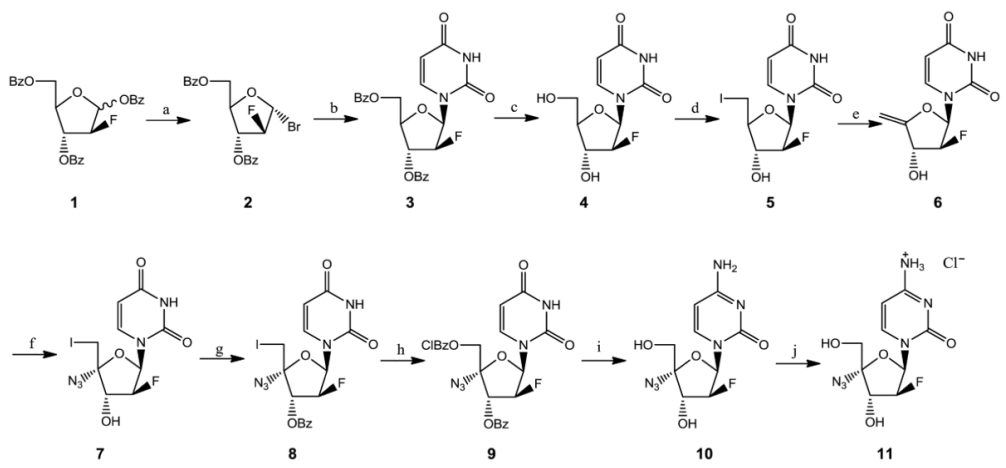

Scheme 1.

Reagents and conditions: a) $\mathrm{HBr} / \mathrm{HOAc} / \mathrm{DCM}$; b) silylated uracil(5-fluorouracil)/ $\mathrm{CHCl}_{3}$; c) $\mathrm{NH}_{3} / \mathrm{MeOH}$; d) $\mathrm{Ph}_{3} \mathrm{P} / \mathrm{I}_{2} / \mathrm{DMF}$; e) NaOMe/THF; f) ICl/NaN $3 / \mathrm{THF}$; g) BzCl/Pyr.DCM; h) $\mathrm{mCPBA} / \mathrm{mCBA} / \mathrm{DCM}$; i) 1. triazole/ $\mathrm{POCl}_{3} /$ pyridine/DCM, 2. $\mathrm{NH}_{4} \mathrm{OH}, 3 . \mathrm{NH}_{3} / \mathrm{MeOH}$; j) $\mathrm{HCl}, \mathrm{MeOH}, \mathrm{EtOAc}$. 


\section{Table 1}

Anti-HIV activity of $\mathbf{1 0}$ and $\mathbf{1 1}$ against wild-type HIV-1 virus.

\begin{tabular}{cc}
\hline Compound & $\mathbf{E C}_{\mathbf{5 0}}(\mathbf{n M})($ wild-type) $\boldsymbol{a}$ \\
\hline $\mathbf{1 0}$ & 0.3 \\
$\mathbf{1 1}$ & 0.13 \\
$\mathrm{EFV}$ & 1.2 \\
$\mathrm{AZT}$ & 47 \\
\hline
\end{tabular}

${ }^{a} \mathrm{EC}_{50}(\mathrm{nM})$ is the concentration that inhibits HIV by $50 \%$. Results were averaged from at least two separate experiments. 
Table 2

Anti-HIV activity of 11 against NL4-3 (wild-type), NL4-3 (K101E), and RTMDR.

\begin{tabular}{cc}
\hline Compound 11 & $\mathbf{E C}_{\mathbf{5 0}}(\mathbf{n M}) \boldsymbol{a}$ \\
\hline NL4-3 & 0.086 \\
NL4-3.K101E & 0.15 \\
HIV-1RTMDR & 0.11 \\
\hline
\end{tabular}

${ }^{a} \mathrm{EC}_{50}(\mathrm{nM})$ is the concentration that inhibits HIV by $50 \%$. Results were averaged from at least two separate experiments. 
Table 3

Anti-HIV activity of compound $\mathbf{1 1}$ against NIH reagent program NRTI-resistant virus panel.

\begin{tabular}{ll}
\hline NRTI Resistant Virus Panel & EC $_{\mathbf{5 0}}(\mathbf{n M})$ \\
\hline 7324-1 (M41L, D67N, K70R, T215F, K219E, T69N) & 0.595 \\
7324-4 (M41L, K70R, T215F, K219E) & 0.735 \\
10076-4 (M41L, T215Y, M184V) & $>40,000{ }^{b}$ \\
7295-1 (D67N, K70R, T215F, K219Q, M184V, T69N) & $>40,000$ \\
4755-5 (M41L, D67N, L210W, T215Y, M184V, T69D, E44D, V118I) & $>40,000$ \\
6463-13 (M41L, D67N, L210W, T215Y, M184V, V118I) & $>40,000$ \\
7303-3 (M41L, D67N, L210W, T215Y, T69D, E44D, V118I) & 0.56 \\
1617-1 (K70G, M184V, T69K, V75I, F77L, F116Y, Q151M) & 32.2 \\
35764-2 (V75I, F77L, F116Y, Q151M) & 0.42 \\
29129-2 (M41L, D67N, L210W, T215Y, M184V) & $>40,000$ \\
56252-1 (K70R, V75I, F77L, F116Y, Q151M, K65R) & 0.525 \\
NL4-3 (wild-type) & 0.318 \\
\hline
\end{tabular}

${ }^{a} \mathrm{EC}_{50}(\mathrm{nM})$ is the concentration that inhibits HIV by $50 \%$. Results were averaged from at least two separate experiments.

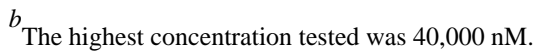


Table 4

Cytotoxicity screening of compound $\mathbf{1 1}$ against six human cell lines.

\begin{tabular}{ll}
\hline Cells & $\mathbf{I C}_{\mathbf{5 0}}(\boldsymbol{\mu M})$ \\
\hline TZM-BL (derived from Hela Cells) & $>140^{b}$ \\
HEPG-2 & $>140$ \\
$293 \mathrm{~T}$ & $>140$ \\
MT4 & 0.12 \\
ACH-2 & 0.11 \\
PBMC (PHA activated) & 0.15 \\
\hline
\end{tabular}

${ }^{a} \mathrm{IC} 50(\mu \mathrm{M})$ is the concentration that inhibits cell growth by $50 \%$. Results were averaged from at least three separate experiments.

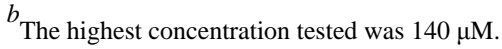

